\section{Structure of Pearls.}

THE origin of pearls has been a subject of speculation of both laymen and men of science alike. In the literature on this subject, one finds that most of the scientific work has been done on pearls of commercial value, such as those from Margaritifera vulgaris, M. margaritifera, and Mytilus edulis, and that those from other molluscs, like Pinna, have been studied only by a few workers. Réaumur (Mémoires de l'Académie des Sciences; 1717) stated that shell extrusions were the causes of pearl formations in Pinna. Raphaël Dubois (Annales de l'Université de Lyon, Fasc. 29 ; 1909) on Pinna pearls states, "Je n'ai jusqu'à présent jamais rencontré dans le noyau des perles de Pinna rien qui ressemblât à un Distome ou à un Ver quelconque. Mais, dans deux exemplaires, dont un est né dans le pare du laboratoire, j'ai vu très nettement de petits corpuscles ovoïdes, de

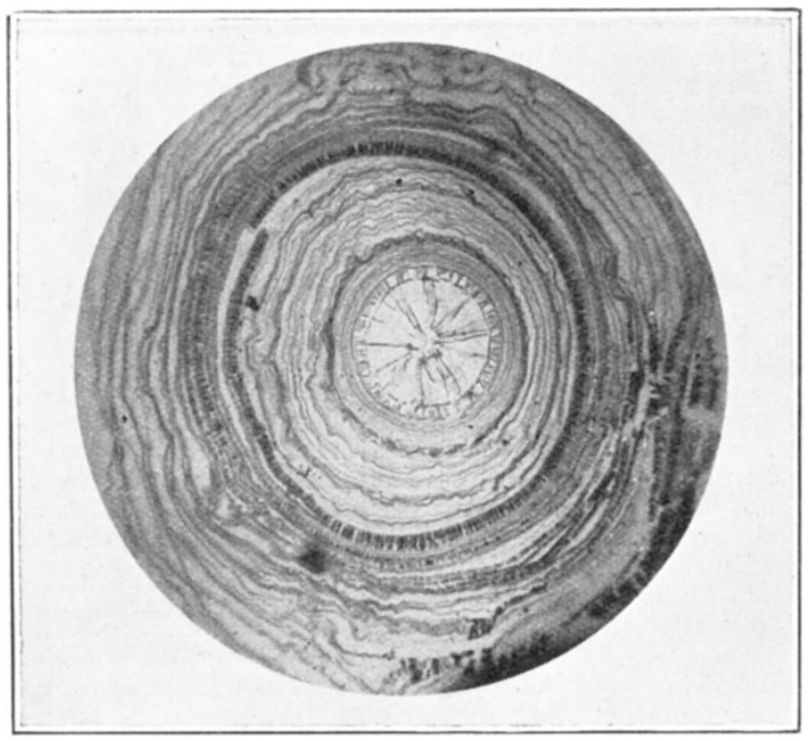

FIG. 1

1 centième de millimètre, dans l'intérieur du noyau ; ils étaient semblables à ceux que j'ai signalés dans les perles de Pintadines du Golfe de Gabès et dans les perles de Modioles de la mə̂me localité. Je les considère comme des spores de sporozoaires.'

Thirty-two pearls from the tissues of a Pinna, dredged in the Salcombe Estuary in February 1928, were kept in Dubosq-Bouin for about nine months to dissolve the calcium carbonate and to fix any soft organic matter that may be present. All the specimens were dehydrated, cleared, and sectioned by the usual method; four of these could not be completely sectioned as the nucleus fell out in the process. The sections were stained either in iron hæmatoxylin and eosin or in water-blue and safranin. From the work of Alverdes (Zeitschr. wiss. Zool., Bd. 105; 1913), it is known that water-blue stains the conchyolin of the nacreous layer, and safranin the periostracum.

On microscopic examination, sections of twenty pearls showed that there were few concentric conchyolin bands in which the supporting organic matrix was radiating out in a manner similar to that found in the shell of Pinna as shown by Biedermann(Jenaische Zeitschr. f. Naturwiss., Bd. 36; 1902 ; Taf. 1, Fig. 5); the arrangement of the layers in seven other pearls showed that it was identical with that found in 'white' pearls of Ostrea edulis, except that there were no discontinuous layers of brown horny material; one pearl had an alveolar layer round the nucleus, with the normal arrangement of concentric layers on the periphery, as shown in Fig. 1, and still another had an alveolar layer on the outside, added to the two layers already present as described in the previous one.

It was also observed that one pearl had small ovoid corpuscles in the nucleus, probably similar to those found by Dubois (loc. cit.); one had a network of conchyolin which stained blue, indicating that before decalcification there was a piece of nacreous material ; eight had an irregular mass of conchyolin, the remnant of an amorphous layer ; twenty-one had brown conchyolin which was not acted upon by either of the stains, and finally, the nucleus of one could not be ascertained. Thus it would appear that in Pinna, the origin of pearls is due to abnormal secretion of the epidermis, a view similar to that enunciated by Jameson (Proc. Zoo. Soc., 1912) for the Ceylon pearl oyster.

C. Amirthalingam. Zoological Dept.,

University College, London.

\section{The Methodology of the Inexact Sciences.}

ON the rare occasions when I dip into some book on one of the non-quantitative sciences, such as those which deal with folk-lore, analysis of literary documents, or the human unconscious, I am puzzled and a little scandalised by a canon of logic which appears to be very freely adopted in these branches of thought. It consists in the use of the following argument: "It is possible to work out an analogy between $A$ and $B$. Therefore $A$ must be the cause of $B$, or vice versa." This canon used to be used very freely in the interpreta. tion of sacred writings, and especially of prophecy, but it seems now to have passed over intact into the sciences I have mentioned above.

To give one example: in the very interesting article on "Christmas Customs and their Origins" in NATURE of Dec. 22, it was stated that "the Cave of Mithra survives in the cult of the Manger" of Bethlehem. The reason implied for this attribution is that there are two analogies between the two cults - (1) That both relate to events which took place indoors (any event must take place either indoors or out of doors, so that the coincidence is not a very surprising one); and (2) that in both cults animals are represented. It happens that the Mithraic animals-the snake, bull, scorpion, and dog-are different from those found in the stable, but in any case amongst agricultural people animals are so ubiquitous that there seems to be nothing very remarkable in the fact of their presence. This, then, is the argument: "In Mithraism and in the Catholic Crèche you have (1) an indoor transaction, and (2) animals present (although of different species and characters); hence the cult of the manger is a survival of Mithraism.'

Arguments of this type constantly recur in the nonquantitative sciences-notably in the phallic interpretation of dream symbols. They appear to me to be fallacious, for the reason that it is almost always possible to trace an elaborate analogy between any two groups of events whatever, chosen at random. Any biography can be used to interpret any dream: Freud's "Gradiva" affords an outstanding example of this fact.

There is, of course, no harm whatever in the innocent pursuit of tracing such analogies, but it seems extremely misleading to apply the same term, 